\title{
PSYCHIATRY, CRIMINAL LAW, AND THE ROLE OF THE PSYCHIATRIST
}

\author{
Ralph Slovenko*
}

\section{INTRODUCTION}

$I_{\mathrm{is}}^{\mathrm{T}}$ $T$ IS TIME to take exception to the indictment that psychiatry is undermining individual responsibility and subverting the criminal law process. ${ }^{1}$ The charge should more appropriately recite that those persons who are longing for certainties and freedom from individual responsibility are abdicating and casting the responsibility for decision-making to psychiatrists.

The "psychiatrization" of the criminal-law test of responsibility is regarded by critics as a prime illustration of the alleged debilitating effect of psychiatry. Professor Jerome Hall, among others, says that the campaign by psychiatry has been relentless to destroy the McNaghten "right and wrong" rule of criminal responsibility (which somehow or other is tied in with the concept of individual responsibility). ${ }^{2}$ Professor Hall tells us that "the propagandists now agitate for the abolition of all legal tests," and he exclaims that "the propagandists of the new conception of man are organized and endowed with vast sums of money taken from the pockets of unorganized citizens who are helpless to check the onslaught."

* LL.B., M.A., Tulane University. Associate Professor of Law, Tulane University. The author wishes to thank Drs. Frank Silva, John Trice and Gene Usdin for helpful discussions. The author, however, takes sole responsibility for the views expressed.

${ }^{1}$ A recent jeremiad which has received considerable attention is sociologist Richard LaPiere's THE Freudian EtHIC (1959), subtitled AN ANAlysis of the Subversion of American Character. See further Schoeck \& Wiggins, Psychiatry and Resonsibility (1962). Psychiatry is also called a threat to civil liberties. Szasz, Psychiatry's Threat to Civil Liberties, National Review, Mar. 12, 1963, p. 191. The various and sundry criticisms directed against psychiatry are collected in Miller \& Halleck, The Critics of Psychiatry: A Review of Contemporary Critical Attitudes, 119 Ax. J. OF Psychiatry 705 (1963).

2 Professor Hall's observations quoted herein are from his article The Psychiatrist and Crime: $A$ Threat to Society?, National Observer, Aug, 20, 1962. Professor Hall supports the McNaghten rule in General Principles of Criminál Law 500-18 (2d ed. 1960); Psychiatry and Criminal Responsibility, 65 YALE L.J. 761 (1956); and Responsibility and Law: In Defense of the McNaghten Rules, 42 A.B.A.J. 917 (1956). 


\section{Insanity at TIME OF OfFENSE}

Our system of jurisprudence for a long time has maintained that an individual should not be held responsible for his actions when he does not know what he is doing or when he is "sick." The difficulty has been in applying this general principle. Jurists, psychiatrists and others have spent countless hours trying to formulate a rule that will determine when a man is sufficiently demented to be no longer held accountable for what he does. The formulation of the rule theoretically determines the function of the court, the function of the jury, the instructions, and the scope of the evidence.

The case in 1843 of Daniel McNaghten has been told ad nauseam, but we restate it for the sake of clarity. McNaghten, a paranoid schizophrenic, heard God telling him that Sir Robert Peel, the Prime Minister of Great Britain, was not really Sir Robert Peel but the devil in the flesh, and if he would destroy Peel, all Europe would accolade him as a savior. McNaghten stationed himself outside Peel's house and shot the first man with a high hat, who turned out to be Edward Drummond, the private secretary of the Prime Minister. McNaghten then got up on the steps and demanded the passersby to bow down before him. "I have," he cried out, "rid Europe of a monster." He was tried and acquitted. It was obvious, in popular parlance, that he was crazy. The acquittal, however, was the beginning rather than the end of this celebrated case. ${ }^{3}$

The House of Lords, exercising its special constitutional right, consulted the judges upon the law relating to insanity. The judges' answer, known as the McNaghten rule, was put in the following terms:

The jury ought to be told in all cases that every man is to be presumed to be sane, and to possess a sufficient degree of reason to be responsible

${ }^{3}$ The story has its variations. "[McNaghten, a paranoiac,] suffered from delusions of persecution as a result of which he had visited various countries in an attempt to escape from his persecutors. His complaints to his parents and to public authorities were unavailing, and he became embittered. So, with the object of drawing attention to his case and of righting his supposed wrongs, he devised a plan to kill Sir Robert Peel. He kept a watch on his house, and when he saw a man come out, he shot Mr. Drummond under the mistaken belief that he was shooting Sir Robert Peel . . . [The defense's] plea [of partial insanity] was upheld and McNaghten was certified as of unsound mind and detained in a lunatic asylum. The verdict in the above case created a great sensation and much controversy ensued. A few days after the trial the case was debated in the House of Lords ...." Henderson \& Gillespie, Psyciriatry 549 (9th ed. 1962). 
for his crimes, until the contrary can be proved to their satisfaction; and that, to establish a defence on the ground of insanity, it must be clearly proved, that, at the time of the committing of the act, the party accused was labouring under such a defect of reason, from disease of the mind, as not to know the nature and quality of the act he was doing, or, if he did know it, that he did not know he was doing what was wrong.

Thus, under the McNaghten rule, crime is excused when the individual is so mad as not to know the difference between right and wrong. Defect of cognition as a consequence of mental disease is the primary exculpating factor under the rule.

It is often stated that "Western civilization rests on the premise that normal adults are rational and therefore have a very significant sphere of freedom and autonomy." 4 The McNaghten test is a child of the Age of Reason, but even earlier, Aristotle postulated that the essence of man is rationality. The dictum, "Cogito, ergo sum," "I think, therefore I am," is, however, the formula for the schizoid intellectual's struggle to possess an ego. A healthy human being would be more likely to start from "I feel, therefore I am." The McNaghten rule does not do justice to the emotional and irrational aspects of human personality, and these are too important to be overlooked.5 Psychiatrists do not speak with one voice but at least show certain areas of agreement; they point out the profound influence upon our everyday behavior of thoughts and feelings of which we are usually unconscious, and they stress the importance of events in the first five years of life in shaping those aspects of our adult personalities of which we tend to be least aware. Intelligence, they

\footnotetext{
Hall, The Psychiatrist and Crime: A Threat to Society?, National Observer, Aug. 20, 1962.

The desideratum, an amalgamation of thought and feeling, is expressed in Norman Brown's Life Against Death (1959) and Ferbert Marcuse's Eros and CrvilizaTroN (1955) as "Dionysian Ego" or "libidinal rationality," a goal which unfortunately has been misconstrued as anti-intellectualism, anti-rationalism, beatnikism. See Roszak, The Fistorian as Psychiatrist, The Nation, Nov. 24, 1962, p. 343.

A considerable number of American intellectuals today are opposed to liberalism and tolerance. Overreacting to the bondage of the past, they present a kind of antiintellectual intellectualism which is pure "no-nothingism." Letter from Paul Peters, a former editor of Life and now editor of Image, to the author, March 22, 1963. There is a vital difference, it seems to be forgotten, between thought and action. It is possible, believe it or not, to be just to a hated man. To say that one ought to ventilate hate by spitting in another's eye, to put thought into action, is a gross distortion of Freud. According to Freud, there is value in becoming conscious of the reasons for hate; the feelings may then be handled effectively and constructively. The Age of Reason, it seems, is still in the future.
} 
point out, is not to be equated with mental health. ${ }^{6}$ Mental institutions have their quota of Ph.D.'s. Consider, for example, the notorious case of Bill Heirens, a brilliant college student, who butchered a little girl and threw her dismembered limbs into a sewer, and who wrote on the wall of one victim's apartment, "For God's sake, catch me before I do this again." Consider also the case of the birdman, now idolized in film. Even though of superior intelligence, he shot a man over a prostitute for whom he was pimping, attacked an orderly and tried to stab him to death, and assaulted a mentally retarded boy.

The McNaghten "knowledge of right and wrong" test of criminal responsibility continues to be the law of most American states and federal jurisdictions. The McNaghten test is intellectualistic and moralistic, not medical. ${ }^{z}$ Medical madness is not McNaghten madness. ${ }^{8}$ In testifying under the rule, literally and strictly applied, a psychiatrist is out of bounds in presenting evidence of the individual's mental status or capacity to control conduct. The evidence would not be responsive to the issue.

The truth of the matter, however, is that the McNaghten rule,

- The mental defective has less intellect to deal with the ordinary things in life, hence they are apt to appear more dangerous and devastating to him. As Winnicott puts it:

Where there is restricted intellectual capacity (based on poor brain-tissue endowment) the infant's capacity to convert not-quite-good-enough environmental adaptation into good-enough environmental adaptation is lowered, with the result that certain psychoses are more common in defectives than in the normal population. Exceptional brain-tissue endowment may enable an infant to allow for a severe failure of adaptation to need, but in such a case there can be a prostitution of mental activity so that one finds clinically a hypertrophy of intellectual processes related to a potential schizophrenic breakdown. WinNicort, CoLtected Papers 225 (1958).

Yet intelligence does not give immunity against mental disorder. The paranoid personality, for example, is so often not lacking in intelligence. Also, as student counsellors can readily attest, the super-I.Q. students contribute their share of disciplinary problems at school; they are often cold and isolated individuals, lacking in interpersonal rela. tions. In recovery, the intelligent person generally has an advantage over the sub. normal inasmuch as intelligence is ego binding.

${ }^{7}$ Mental abnormality is variously defined for different purposes. For the purposes of psychiatry, see American Psychiatric Association, Diagnostic and Stitistical. Manual on Mental Disorders. For the purposes of the law, the definition of mental illness is different. Hence, it is incumbent upon the legislature to be explicit atrout the meaning of "mental disease" when used in various legal contexts, as for example civil commitment, testamentary capacity, traumatic neurosis, criminal responsibility. See Swartz, "Mental Disease": The Groundwork for Legal Analysis and Legislativ Action, 111 U. PA. L. REv. 389 (1963).

${ }^{8}$ See Brain, The Languages of Psychiatry, 109 British J. Psychiatry 4 (1963). It is interesting to observe that the determination of insanity is somewhat tautological: a normal person would not commit an abnormal act; he did it, so he must be abnormal. The evaluation is circular, but pragmatic. Legal insanity tends increasingly 
while given Jip service, has long been dead. ${ }^{\circ}$ It is generally acknowledged that the rule has been interpreted liberally, admitting psychiatric testimony without limit. ${ }^{10}$ Thus applied, the rule has survived the years. If the rule were applied otherwise, extremely few individuals would ever be found legally insane. Indeed, there

to be diagnosed only by the offender's inability to accommodate himself to the demands of the society.

- Adherence today to the old McNaghten rule of 1843 , which has now reached the age of six score years, may be taken to signify any of the following:

(1) Psychiatry or law has not progressed during the past 120 years. Dr. Franklin G. Ebaugh and Dr. John M. Macdonald, Denver psychiatrists, contend that the law covering insanity in criminal cases is "so archaic that it is dangerous." Ebaugh \& Macdonald, The Medicolegal Dilemma-An Interment of Truth, 184 J.A.M.A. 131 (1963).

(2) No change or improvement is needed in the law.

(3) The McNaghten rule as formulated is a dead horse and is only given lip service.

(4) Criminal responsibility under the McNaghten rule involves a moral issue, and psychiatrists have no special competence in that province.

It is appropriate to note here the contention that the court should abandon the McNaghten rule and adopt a rule excusing from crime the act of a defendant which is the product of mental disease or defect but leaving the exact definition of "insanity" to the jury, just as in the law of tort where the definition of "reasonable man" is left to the jury based upon its experience and common sense. Critics of the McNaghten rule argue that the writing into law of a rule based on a legal understanding of medical knowledge existing at the time of the establishment of the rule is subject to inevitable and eventual difficulty. Because of the doctrine of stare decisis, a definition in a rule of law will not be able to conform to changes in science and human understanding. Hence, it is argued, the McNaghten rule ought to be discarded, replacing it by Durham or Currens (discussed infra), where the matter is substantially left to the decision of the jury upon the broadest possible base of medical and lay testimony. It is, however, an error to assume that the McNaghten test sets out a medical definition. To repeat, McNaghten madness is not medical madness. Hence developments in medical science do not outmode the legal definition. On the other hand, a moral definition, which McNaghten sets out, is not so readily dated by the doctrine of stare decisis. Indeed, one might say that this danger can more readily occur under the Durham or Currens tests. It is perhaps inevitable that these tests will be (and are) administered so as to make "mental disease or defect" a jural rather than a psychiatric definition.

${ }^{20}$ Charles E. Clark, U.S. Circuit Judge and former dean of the Yale Law School, says: "This test is sufficiently vague that sympathetic judges and juries, if so minded, can show mercy to the mentally diseased under indictment." Clark, Book Review, The Nation, Jan. 12, 1963, p. 36. In Judge Cardozo's words, the McNaghten rule refers to the "true capacity of the individual." Cardozo, The Psychiatry of Criminal Guilt, in Gahn, Social Meaning of Legal Concepts (1960). More and more, McNaghten madness appears to be equated with medical madness.

The situation in England and Scotland is apparently the same. See MAYER-Gross, Slater \& Roth, Cuinical Psychiatry 611 (2d ed. 1960); Yellowlees, To Define True MADNESS 146 (rev. ed. 1955).

One might compare the McNaghten situation with the law and practice relating to the procuring of abortion. The solution generally has been to lay down the simple, general law that it is illegal to procure abortion, and to leave it to be understood that nothing will be said if medical men of standing procure abortion for bona fide therapoutic purposes, after due consideration and without improper secrecy. YellowleEs, op. cit. supra at 146. 
is hardly a patient in a mental hospital who does not know the difference between right and wrong. Strict adherence to the rule and a strict construction of it would send just about all persons who commit a criminal act to prison. ${ }^{11}$

In 1954 the Court of Appeals for the District of Columbia, in the Durham case ${ }^{12}$ decided no longer to give lip service to the fiction developed under the $M c N a g h t e n$ rule. It decided to call a spade a spade. The Durham rule of insanity is that "an accused is not criminally responsible if his unlawful act was a product of mental disease or mental defect."13 While this is how the McNaghten rule has generally been interpreted in practice, the Durham rule without subterfuge gives psychiatrists free range to testify. It expressly brings into trial all the medical facts in medical terms. The Durham decision expressly states that the purpose of the rule is to get good psychiatric testimony, all of the psychiatric testimony. By dropping the notion of responsibility based upon cognition in favor of capacity or controllability, the court sought to clarify the prevailing practice, to bring it out into the open, and to allow testimony without the "straight jacket of the law." Judge Bazelon, the author of the opinion, knew what he was about, but a new formulation of

\footnotetext{
11 Lord Brougham observed, "Nobody is hardly ever really mad enough to be within the definition of madness laid down in the [McNaghten rule]." Quoted in HeNDERSON \& Gillespre, Psychiatry 551 (9th ed. 1962). In a literal application of the McNaghten rule, two (and probably only two) classes of law-breakers would be exempted from punishment. For example, in the case of homicide: (a) the person thought that the gun with which he shot somebody was not a deadly weapon but a water pistol, and was therefore unaware of the fact that it would kill (he did not "know the nature and quality of the act he was doing'); or (b) the person labored under the delusion that he was physically attacked and acted in legitimate self-defense ("he did not know he was doing what was wrong'). The McNaghten rule, by the way, does not ask whether the law-breaker knew the difference between right and wrong. It asks whether he "knew he was doing what was wrong" or, perhaps, thought he was doing what was right; that is, whether he was under a delusion to act in legitimate self-defense.

On the other hand, a paranoiac with delusional ideas to the effect that someone is destroying his social position by spreading vicious rumors about him (c.g., that he is a homosexual) would not be exempt from punishment because, if the content of his delusional ideas were true, he still would not have the right to kill his pursuer but would have to seek redress in some other way. This is spelled out in the second McNaghten rule which stipulates with reference to what it calls "partial delusions" that the law-breaker "must be considered in the same situation as to responsibility as if the act in respect to which the delusion exists were real." That is, it must be asked whether a person would be liable to punishment if it were true tbat his victim had spread vicious rumors about him but he would not be liable to punishment if it were true that he defended his life.

${ }_{12}$ Durham v. United States, 214 F.2d 862 (D.C. Cir. 1954).

${ }^{13}$ Id. at 87. See also Krash, The Durham Rule and Judicial Administration of the Insanity Defense in the District of Columbia, 70 YALE L.J. 905 (1961).
} 
a rule in new language brings new difficulties in interpretation in its wake. Judges and juries in subsequent cases have been mired in confusion over the terms "disease," "defect" and "product." The test "product of a mental disease or mental defect" does not guide the jury, for example, as to the degree of mental disease or defect. In psychiatric nomenclature the term "mental illness" includes psychosis (major mental illness) and neurosis, but the term in the Durham rule has been construed to include the personality disorders, the "psychopathic and sociopathic personalities" (antisocial individuals). ${ }^{14}$ Judge Holtzoff remarked, "It is not inconceivable that

14 See Blocker v. United States, 274 F.2d 572, 573 (D.C. Cir. 1959); Briscoe v. United States, 248 F.2d 640, 643-44 \& n.6 (D.C. Cir. 1957). The concept and definition of the psychopathic or anti-social personality has not been clearly handled in the law, or it has been distorted under the legal definition of insanity. The psychopathic personality, commonly called sociopath, falls among the personality disorders. He differs from the psychoneurotic or psychotic, and indeed contrasts with them in the most important characteristics, yet some courts form the impression that the psychopathic personality suffers from mental illness. The etiology of the words "pathology of the psyche" is misleading. The old term "moral insanity" is a better description. The psychopathic personality is not so much a disorder as it is a defect, a failure of development.

To give an analogy, which I owe to Dr. Cyril Phillips, dwarf orange trees, grown by a special technique to be a few inches high at maturity cannot be said to be sick or diseased trees. They are clearly distinguishable from full-size ones in a grove which have become infected. It is also clear when such a dwarf tree is healthy, or infected or diseased. In the same way it is possible to consider a psychopathic personality as a dwarf tree, with limited function, e.g., ornament, fundamentally unalterable and free from disease. Leaving the analogy at this point, it is theoretically possible to change a psychopathic personality by the prolonged application of a high degree of skill such as we may hope to find among psychoanalysts with a special preference for this work or in the lighlest grade institutions. At present this can only be achieved as a "laboratory" experiment.

The symptoms of a delinquent provide pleasure in contrast to the symptoms of a neurotic or psychotic which yield displeasure. The psychotic may waste his energy in hallucination; the neurotic, driven by phobias, may witldraw to his room-not the delinquent. He acts out; he makes life miserable for otlers. He is unwilling or unable to give preference to value enforcement over immediate gratification. He "smiles and sucks," and if this fails, he "bites and runs." The delinquent does not suffer unless he is cauglit and fears punishment. He laughs at the psychiatrist. He is not in distress, a sine qua non for effective treatment. He is markedly lacking in ability to observe himself. Eissler, Some Problems of Delinquency, SEArchughts ON DELINQUENCY 3 (Eissler ed. 1949).

Hervey Cleckley, in his beok THE MASK OF SANITY (1941), lists the characteristic points distinguishing the psychopatl as follows: (1) superficial charm and good "intelligence" (which makes it clear that his behavior cannot be explained on the basis of mental deficiency); (2) absence of delusions and other signs of irrational "thinking" (thus this excludes psychotic disorders such as schizoplrenia); (3) absence of "nervousness" or psychoneurotic manifestions; (4) unreliability; (5) untruthfulness and insincerity; (6) lack of remorse and shame; (7) inadequately motivated antisocial behavior; (8) poor judgment and failure to learn by experience; (9) pathologic egocentricity and incapacity for love; (10) general poverty in major affective reactions; (11) specific loss of insight; (12) unresponsiveness in general interpersonal relations; 
perhaps the so-called Durham formula would not have been adopted if it had been foreseen at the time that it would lead to the exculpation of sociopaths or psychopaths from criminal liability."16

Disillusioned by both the McNaghten rule and the Durham rule, the Court of Appeals for the Third Circuit in the Currens case ${ }^{10}$ came up with a formula drawn in part from a test proposed by the American Law Institute in its Model Penal Code. The test set out in the Currens case is that criminal responsibility will be imposed upon the accused where he was not suffering from a disease of the mind, or, even though suffering from such mental disease, where he possessed "substantial capacity" to conform his conduct to the requirements of the law at the time of the criminal act. ${ }^{17}$

The Currens test will probably have a fate no better than Durham, for a formula should pay some respect to empiricism. Except in the unusual case where a person is directed by hallucination to commit a crime, it would be well-nigh impossible to determine whether the diseased or healthy part of the individual's mind led

(13) fantastic and uninviting behavior, with drink and sometimes without; (14) suicide rarely carried out; (15) sex life impersonal, trivial, and poorly integrated; and (16) failure to follow any life plan. See also Jenkins, The Psychopathic or Antisocial Petsonality, 191 J. Of Nervous and Mental Disease 318 (1960).

${ }^{15}$ O'Beirne v. Overholser, 193 F. Supp. 652, 660 (1961). Guttmacher, The Psychia. trist as an Expert Witness, 22 U. CHr. L. REv. 325 (1955), predicted that Durham would not be easy to administer. The problems of Durham in the District of Columbia are described in Campbell v. United States, 307 F.2d 597 (D.C. Cir. 1962); Blocker v. United States, 288 F.2d 853 (D.C. Cir. 1961).

${ }^{16}$ United States v. Currens, 290 F.2d 751 (3d Cir. 1961).

${ }^{17}$ See Diamond, From M'Naghten to Currens, and Beyond, 50 CaltF. L. REv. 189 (1962).

The rulings by the United States Supreme Court on the issue of criminal responsibility are both old and oblique. See Matheson v. United States, 227 U.S. 540 (1913); Davis v. United States, 160 U.S. 469 (1895), I65 U.S. 373 (1897). There is a vast amount of literature and cases on the subject, but courts, attorneys, law professors and psychiatrists remain divided on the best approach. Sec ToMphINS, INSANITY AND TIE, CRIMINAL Law: A Bibliography, Bureau of Pub. Ad., U. Calif., June, 1960. It is therefore a bit of wisdom on the part of the Supreme Court not to freeze the stewing by a grant of ccrtiorari. In the Currens case Judge Biggs states:

We think that perhaps the Supreme Court has withheld the granting of certiorari in such cases as Sauer v. United States, [241 F.2d 640 (9th Cir.), cert. denied, 354 U.S. 940 (1957)], and has not laid down a rule for the federal courts in respect to criminal responsibilty of the mentally ill because it desires to treat the circuits as it does the States, as laboratories for the development of substantive law. 290 F.2d at 769.

The following circuits have recently declined to revise the existing rule: Beltran v. United States, 302 F.2d 48 (1st Cir. 1962); Fitts v. United States, 284 F.2d 108 (10th Cir. 1960); United States v. Westerhausen, 283 F.2d 844 (7th Cir. 1960); Voss v. United States, 259 F.2d 699 (8th Cir. 1958); Andersen v. United States, 287 F.2d 118 (9th Cir. 1956); Howard v. United States, 232 F.2d 274 (5th Cir. 1956) (abrogation 
him to his crime.18 A person can have a "touch" of schizophrenia, unlike the possibility of having a "touch" of pregnancy, which is an all-or-none situation. In addition, and most important, a test must be fairly cleancut and reasonably simple. ${ }^{19}$ The test, after all, is going to be applied by a jury of laymen, twelve ordinary men. The Currens test is too complex for use in the court room, or anywhere else for that matter. There are few lawyers, much less laymen, who understand it.

The Durham decision, initially supported by many, and the Currens decision are faced each year with a growing negative reaction. Perhaps a spade ought not to have been called a spade. While we may generally endorse the abandonment of disguise, we ought however to pay attention to the words of Oscar Wilde: "A man who calls a spade a spade is fit only to use one." There is no desire here to advocate one rule of criminal responsibility over another, or to prate about the difference, if any in actual operation, between the rules. Indeed, the McNaghten rule, urged by Professor Hall and others, has advantages not provided by the other rules. The jury has an easier task with the McNaghten rule, narrowly or broadly applied, than with the other rules, and that is highly important for the fair administration of justice..$^{20}$

Some say that the crucial issue is whether the courts should determine the test for responsibility and have medical witnesses direct their testimony to that test, or whether the medical profession itself should determine legal responsibility. This formulation of the issue, however, does not put the matter in proper focus.

of McNaghten was argued before the Fifth Circuit en banc in Carter v. United States, May 28, 1963).

For a listing of states which follow each specific rule, see Note, 15 Vand. L. REv. 274, 276 n.18 (1962).

${ }^{18}$ Slovenko \& Super, The Mentally Disabled, The Law, and The Report of the American Bar Foundation, 47 VA. L. REv. 1366, 1383 (1961). Furthermore, the meaning of "substantial" is different for each person. One may contend that the jury decision affords an adequate amalgamation of opinion, in other words, a hodge-podge answer coming out in a "yes" or "no" verdict.

${ }^{10}$ Indeed, defense counsel have quite enough to do in preparing a defense that the defendant was not involved in the commission of the act. At the trial stage of the proceeding, defense counsel is overwhelmed by exploration of anything else. In a recent reaffirmance of the McNaghten rule, the Washintgon Supreme Court observed that any other rule would be difficult to apply. State v. White, 374 P.2d 942 (Wash. 1962).

${ }^{20}$ Jurors do not understand the McNaghten test, much less the Durham or Currens tests. On the basis of informal studies, it appears that jurors decide wtihout considering the test, but the tendency is to acquit because jurors consider it unfair to 
First, why have a formula at all? The juvenile court (while perhaps subject to criticism on other grounds) gets along quite well without one. What is the value of a formula of irresponsibility? To allow liberty to persons proven dangerous? To send incurables and uncontrollables to the hospital? To allow them to disrupt the hospital society as they have disrupted the community from which they came? To sidetrack witnesses, judge and jury into moral and theoretical questions which are impossible to answer? The law is obsessive-compulsive by nature; it, of all disciplines, notably puts things in brackets, yet we must remember, as Humpty Dumpty cautioned, never to let words or brackets be the master. Guttmacher and Weihofen put it this way:

Fundamentally, why should it make any difference whether a person who has committed a criminal act was sane at the time and therefore guilty, or not guilty by reason of insanity? In either case he has shown himself a menace to society who must be taken into custody and control. Why worry over whether that control is based on criminality or insanity?21

A motorist has a heart attack or an epileptic fit and hits a pedestrian; a man squeezes his wife's throat thinking that he is squeezing a lemon; a man shoots a policeman thinking he is the devil; a woman, concretely interpreting the scripture that one knows God only by drinking the blood and eating the flesh, cooks and eats her newborn child. These persons are all responsible for their acts. Who else, if they are not? As the Eichmann trial may remind us, everyone must

convict when they do not understand the instructions. One judge observed, "In criminal cases after three days of trial they [the jury] usually evaluate the prisoner and determine whether or not he is a crook and should be placed in jail or honest and should be released. That is about it." Symposium: The Law and Psychiatry, 109 J. of LA. State Med. Soc. 141, 157 (1957).

One difficulty with the McNaghten rule arises in the charge to the jury. As pointed out, courts usually under the McNaghten rule allow all psychiatric evidence to be admitted at the trial but, through the charge, confuse the jury by instructing it not to consider any except that evidence which relates to cognition. The confusion resulting in the minds of the jurors as a result of the divergence between the evidence presented and the McNaghten charge might, however, be used to justify a literal, strict application of the McNaghten rule, keeping psychiatric testimony entirely out of the trial stage of the proceeding.

${ }^{21}$ Gutmacher \& Weihofen, Psychiatry and the LAW 443 (1952). Similar vicws have been expressed by other writers. Sce Everest, DefENce of INs.inIrY in Criminat, Cases (1887); MacDonald, Psychiatry and the Criminal 29 (1958); Baur, Legal Responsibility and Mental Illness, 57 Nw. U. L. REv. 12 (1962); Scher, Expertise and the Post Hoc Judgment of Insanity or the Antegnostician and the Law, 57 Nw. U.L. REv. 4 (1962). See also Goldstein, J. \& Katz, Abolish the "Insanity Defense"-Why Not?, 72 YaLe L.J. 853 (1963). 
be considered and is responsible for his actions, whatever the origin of the behavior. ${ }^{22}$

Responsibility, however, does not necessarily entail punishment. One may be answerable in other ways. In the case of the epileptic motorist, denial of a driver's license may suffice. In the case of the cannibal, indeterminate confinement may be in order. ${ }^{23}$ In the case of Eichmann, death.

The conventional position is that the district attorney or grand jury, and the policeman too, are invested with broad discretion whether or not to invoke the criminal process. ${ }^{24}$ Thereupon, the district attorney has the power under the law to prosecute or not to prosecute on the charge. ${ }^{25}$ Then there is a preliminary examination and arraignment at which time the judge may dismiss the charge or suspend it on certain conditons. In short, there is considerable flexibility in pre-trial stages. The individual's mental conditionparticularly when he is psychotic-is often in practice taken into account before filing or proceeding on a criminal charge. However, when the case goes to trial, and particularly when the verdict is returned, flexibility in disposition to a considerable extent goes out the window. The judge, one might even suggest, is allowed less discretion than the policeman or district attorney. ${ }^{26}$

At a trial, the fact of the accused's commission of an act that is a menace to society might very well be established apart from any test of responsibility. However, apparently no matter how strongly

${ }^{22}$ Consider also the trial in Israel of the assistant conductor of the National Opera, Hirsch Barenblat, a Jew who as recently discovered, served as a policeman for the Nazi. Refusal to help Eichmann's "transportation" experts would have meant immediate death. Even under duress, cooperation was betrayal. See Time, March 22, 1963, p. 31.

${ }_{23}[\mathrm{~T}] \mathrm{T}$ he disposition of different types of criminals must be individually determined according to the nature of the offender. Some may react favorably to punishment, others require incarceration along with therapy, and again with others there is no alternative but permanent custodial segregation from society. The fundamental principle, however, no matter what practical disposition is made, is that every person must be held responsible for the consequences of his acts. Alexander \&: STAUB, ThE Criminal, The Judge, and The Public 131 (1956).

${ }^{24}$ See Goldstein, A., The State and the Accused: Balance of Advantage in Criminal Procedure, 69 YALE L.J. 1149 (1960); cf. Goldstein, J., Police Discretion Not to Invoke the Criminal Process: Low-Visibility Decisions in the Administration of Justice, 69 YALE L.J. 543 (1960).

${ }^{25}$ See Jackson, The Federal Prosecutor, 24 J. AM. Jud. Soc'y 18 (1940); Slovenko, The Accusation in Louisiana Criminal Law, 32. Tux. L. Rev. 47 (1957).

${ }^{26}$ The policeman or district attorney is allowed discretion because a charge of crime carries consequences almost, if not as serious, as the trial itself. An accusation 
the facts or even practical experience support such a change, it is difficult to make the change in a legal system long designed on a different plan. Under the existing system, however, the McNaghten test, liberally applied, is as good as any of the various moral tests. which the jury may use in deciding guilt or innocence.

Guilt or innocence of crime is a moral or social question, and it is the function of the judge and jury as the community's representative to make that decision and to apply the sanctions deemed appro. priate. ${ }^{27}$ After all, the definition of crime is socially determined. Society decides what is crime, and it has the right to decide what evidence it will hear. The concept of liability in criminal law has its origin in ethics, philosophy and canon law, not psychiatry. The $1843 \mathrm{McNaghten}$ rule, strictly applied, leaves no place whatsoever for psychiatric testimony, yet the psychiatrist nonetheless is continually being called to the stand. Why, but why? Why is he asked to testify whether an accused knows right from wrong? Why is he even summoned to the courtroom? Why is not a cleric or a philosopher called? The psychiatrist is not self-invited; he is not a trespasser. $\mathrm{He}$ is called, and then curiously enough, legal commentators and others complain that psychiatry is corrupting the procedure. One would assume that judge and jury were obtained for the purpose of deciding responsibility. Perhaps judge and jury are not up to the task. There is an old saying that a rescuer is soon looked upon with disdain by the rescued.

Contrary to what is alleged, strict construction of the McNaghten rule ends up with the medical profession supplanting law in determining legal responsibility. Liberal application of the frule, on the other hand, by putting lay or medical evidence before the jury, allows them to think, to weigh the evidence, and to reach a genuine decision of their own. The requirement that a psychiatrist testify solely and entirely in the framework of right-and-wrong operates in action to transfer the responsibility of decision-making from the jury

\footnotetext{
of crime has an infaming effect. Furthermore, unless bail is available, the accused may await trial for months, sometimes years, in a shabby cell in the local jailhouse, where conditions do not nsually measuretup to those in the prison where he is sent following trial and conviction (and time waiting for trial need not be credited towards sentence).

${ }^{27}$ See de Grazia, The Distinction of Being Mad, 22 U. Chr. L. REv. 339, 348 (1955). See also Kuh, Insanity Defense-An Effort to Combine Law and Reason, 110 U. PA. L. REv. 771 (1962).
} 
to the expert (although in theory the ultimate verdict of guilt or innocence lies with the jury). Strict construction and application of the McNaghten rule simplifies the work of the court, or rather, it leaves the court with nothing to do.

All that the psychiatrist can properly do is give his evaluation of the offender's personality, and to leave it to the jury to apply a moral test of guilt or innocence. One might compare medical testimony in personal injury litigation: the proper function of the doctor there is to give evidence on the physical impairment that the victim has suffered, and not the percentage of disability, which is an economic and social issue. In the criminal law process, it is in recommending disposition where the psychiatrist (and also psychologist and social worker) can most helpfully assist the court in arriving at a reasonable disposition of the case through some form or combination of punishment, custody and treatment. ${ }^{28}$ Upon conviction, or ac-

\begin{tabular}{|c|c|}
\hline \multicolumn{2}{|c|}{$\begin{array}{l}{ }^{28} \text { Robert Waelder has suggested the following as a guide: } \\
\text { Diagnostic Characterization } \\
\text { Disposition }\end{array}$} \\
\hline $\begin{array}{l}\text { Dangerous } \\
\text { Deterrable } \\
\text { Treatment }\end{array}$ & Punishment and Treatment \\
\hline $\begin{array}{l}\text { Dangerous } \\
\text { Deterrable } \\
\text { Not treatable }\end{array}$ & Punishment \\
\hline $\begin{array}{l}\text { Dangerous } \\
\text { Not deterrable } \\
\text { Treatable }\end{array}$ & Preventive Custody and Treatment \\
\hline $\begin{array}{l}\text { Dangerous } \\
\text { Not deterrable } \\
\text { Not treatable }\end{array}$ & Preventive Custody \\
\hline $\begin{array}{l}\text { Not dangerous } \\
\text { Deterrable } \\
\text { Treatable }\end{array}$ & $\begin{array}{l}\text { Punishment with Probationary Period } \\
\text { and Treatment }\end{array}$ \\
\hline $\begin{array}{l}\text { Not dangerous } \\
\text { Deterrable } \\
\text { Not treatable }\end{array}$ & $\begin{array}{l}\text { Punishment, perhaps with Probationary } \\
\text { Period }\end{array}$ \\
\hline $\begin{array}{l}\text { Not dangerous } \\
\text { Not deterrable } \\
\text { Treatable }\end{array}$ & Treatment \\
\hline $\begin{array}{l}\text { Not dangerous } \\
\text { Not deterrable } \\
\text { Not treatable }\end{array}$ & Release \\
\hline $\begin{array}{l}\text { Waelder, Psychiatry and the Prob } \\
378,390 \text { (1952). See also RocHE, } \\
\text { Psychiatrist in Determining Crir } \\
\text { Law School, Mar. 20, 1957); Ericks }\end{array}$ & $\begin{array}{l}\text { nal Responsibility, } 101 \text { U. PA. L. REv. } \\
\text { MiND (1958); Monroe, The Role of the } \\
\text { sibility (address delivered at Tulane } \\
\text { and the Law: An Attempt at Synthesis, }\end{array}$ \\
\hline
\end{tabular}


quittal, the court might ask the psychiatrist for his prognosis and the therapy, if any, which might benefit the defendant. ${ }^{29}$ This is indeed the growing practice today in cases of conviction where a pre-sentence report is obtained. In cases of acquittal, however, the criminal court judge in many jurisdictions is without authority to commit under the mental health laws, even when the defendant is in need of immediate care and treatment, or when he is potentially and seriously dangerous to self or others. ${ }^{30}$

It is more than time to shift attention from meaningless refinements in the rule of criminal responsibility to the matter of dis-

1961 Duke L.J. 30; Jenkins, Psychiatry at the Crossroads, 106 Aм. J. of PsycuntnY 358 (1949).

${ }^{20}$ Disposition is a decision left to the judge without the jury. The jury has nothing to do with the question of punishment or treatment (except in capital cases where the death penalty may be remitted), but only with guilt or innocence. Sce, e.g., State v. Doucet, 177 La. 63, 147 So. 500 (1933). Consequently, comment during the trial on a post-conviction rehabilitation program is considered irrelevant. One reason for unjustified acquittals is the repugnance felt by jurors regarding penal treatment. As a general rule, it is a good thing for a person to know the consequences of his decision, yet in criminal administration, jurors go uninformed. See Slovenko, Control Over the Jury Verdict in Louisiana Criminal Law, 20 LA. L. REv. 657, 678 (1960). It is argued that psychiatric testimony ought to be kept out of a trial because it may turn the trial into a "psychiatric seminar," confusing the jury by highly technical language. A special sentencing authority is frequently proposed to decide the appro. priate combination of treatment and punishment. See GLUECK, LAW AND PsYcitiatry (1962); Segre, Criminal Insanity, Wall Street Journal, April 4, 1963, p. 16, col. 3. A literal, strict application of the $M c N a g h t e n$ rule would keep psychiatric testimony out of the trial stage of the proceeding. Few individuals would be acquitted under a literal application of the McNaghten test, and if convicted, the individual could be placed in an evaluation center, such as the Kansas Diagnostic and Reception Center at Topeka, where a rehabilitation program might be worked out. Under Kansas law, the judge on sentencing is given authority to send the convicted person to the Center for sixty days and on the basis of the report, the judge may withdraw or lessen the sentence, place the defendant on probation or arrange some other rehabilitation program. As the judge is not allowed to increase the sentence, it is felt that no one will complain as to the judge's exercise of post-sentence jurisdiction. However, the procedure may result in a tendency to convict. Offhand, it seems that the Kansas law, allowing the formulation of a program during a 60-day post-sentence period, ties in best with a literal application of the McNaghten rule. This will be a curious outcome for the McNaghten rule. There is considerable discussion on the merit of psychiatric testimony during a trial, where as a result of the adversary process and a lay jury, it tends to confusion and misapplication. The McNaghten rule, or no rule, may after all work out best with the expressed desideratum of leaving psychiatric evaluation to the treatment stage, i.e., the post-trial stage. With the development of diagnostic post-sentence clinics, the McNaghten rule may turn out to be the best of the rules (if we must have a legal rule on criminal insanity).

${ }^{30}$ See generally Goldstein \& Katz, Dangerousness and Mental Illness-Some Observations on the Decision to Release Persons Acquitted by Reason of Insanity, 70 YaLE L.]. 225 (1960); Reid, Disposition of the Criminally Insane, 16 Rutcers L. Rev. 75 (1961); Weihofen, Institutional Treatment of Persons Acquitted by Reason of Insanity, 38 
position. ${ }^{31}$ The quest for a formula for guilt or innocence has simply led to garble.

The trouble is not with the formulation, but rather with the basic idea of using a moral test of guilt or innocence that rigidly controls disposition. The solution is not to formulate rules that will be used in a mechanical way to let criminals out on the street; that will displace the prison population into mental hospitals, which then become prisons in disguise; or that will send treatable persons to prisons. ${ }^{32}$ Adequate flexibility ought to be written into the law so as to permit commitment to civil hospitals both before and after indictment or trial, when the defendant would be suitable for the hospital. ${ }^{33}$ Flexibility is the keynote; different methods suit different people. It is the same, for example, with fish: some are speared; others are taken with the line; and others in the encircling net. The McNaghten and other rules of criminal responsibility and the rule on fitness to stand trial are being manipulated and distorted to achieve as best they can this flexibility.

The experience under the Massachusetts Briggs Law ${ }^{34}$ providing for psychiatric examination of all persons accused of certain crimes is reportedly promising. So are the clinics, such as the Baltimore Criminal Court Clinic, designed to aid courts in assessing cases for commitment to mental hospitals, in decisions as to sentencing, and in providing information for probation officers. There are now approximately ten criminal courts in metropolitan centers that have psychiatric clinics as an integral part of the court setup. The clinics vary markedly in their organization and in the manner in which they function. ${ }^{35}$

Texas L. Rev. 849 (1960); Note, 1961 Duke L.J. 481; Comment, Compulsory Commitment Following Successful Insanity Defense, 56 Nw. U.L. REv. 409 (1961).

s1 See Glueck, Crime and Justice 248-80 (1936); Roche, The Crminal Mind (1958).

${ }^{32}$ Slovenko \& Super, The Mentally Disabled, The Law, and The Report of the American Bar Foundation, 47 VA. L. Rev. 1366, 1385 (1961).

ss The judge's discretion to send to a civil hospital, where the law allows it, should be exercised only when the hospital superintendent advises the court that the defendant would be suitable for his hospital. See REPORT AND RECOMMENDATIONS ON Admission to Mental Hospitals under New York Law, Mentai, Illness and Due Process 236 (1962); Rood, The Nonpsychotic Offender and the State Hospital, 115 AM. J. OF Psychiatry 512 (1958). Supervision aids in keeping the hospital alert to its task. The committing court ought to require reports and inquire periodically on the mental status of the person committed. See Smith v. Settle, 211 F. Supp. 514 (W.D. Mo. 1962).

" Mass. Gen. Laws. ANN. ch. 123, §100A (1957).

ss Psychiatric court clinics have been established, and reportedly are successfully 
III

\section{Gapacity to Stand Trial}

The McNaghten rule is concerned only with mental capacity at the time of the offense, only one aspect of the administration of criminal justice. The law has a different definition of insanity at the time of trial. Under the law, an accused is eligible for trial only if he is able to comprehend his position and is able to participate rationally in his defense. ${ }^{36}$ The competency rule is a by-product of the ban against trials in absentia; the mentally incompetent defendant, though physically present in the courtroom, is, in common language, "out of it" and unable to defend himself. The question is usually deferred to medical examiners, who as a rule have little knowledge of what it takes to understand a trial and to assist counsel. $^{37}$ There is perhaps no better person to decide whether the case is triable than the defendant's counsel himself, but being

used, in Baltimore, Chicago, Cincinnati, Cleveland, Detroit, New York, Philadelphia, Pittsburgh, Topeka, and Washington, D.C. Ten psychiatric court clinics have been created in Massachusetts for juvenile and adult criminal courts. See Rymer, The Dilemma of the Psychiatrist in Forensic Practice, 119 AM. J. OF PsYchIATRY 857, 861 (1963). But see Goldstein, A., The Psychiatrist and the Legal Process: The Proposals for an Impartial Expert and for Preventive Detention, 33 AM. J. OF ORTHOPSYchintRY 123 (1963).

${ }^{80}$ The issue is one of procedure rather than substance. As it does not bear on the question of guilt or innocence, a jury trial on the issue is not a requirement. People ex rel. Klesitz v. Mills, 179 Misc. 58, 37 N.Y.S.2d 185 (1942). See also Krash, The Durham Rule and Judicial Administration of the Insanity Defense in the District of Columbia, 70 YALE L.J. 905, 908 (1961).

${ }^{37}$ Judges usually do not adequately instruct the expert on the test of competency. More often than not, the expert is under the impression that he is to apply the much. publicized McNaghten rule of criminal responsibility.

The dual examination, or immediate examination of the defendant's state of mind at time of crime, must face the objection that the constitutional rights of the person might be violated. It is diffcult, if not impossible, to separate the defendant from his crime. Inquiry into facts relevant to the offense is almost inevitable, hence a violation of the privilege against self-incrimination. One might compare Leyra v. Denno, 347 U.S. 556 (1954), a decision to the effect that using a psychiatrist's "wiles" to get information from a criminal suspect amounts to unconstitutional coerced confession. It has been held that a dual examination is not reversible crror when the defendant "does not object and is willing." See State v. Faciene, 233 La. 1028, 99 So. 2d 333 (1957).

Time-of-trial insanity by itself, not being an element of the crime, is not considered an issue for the self-incrimination privilege. On principle, though, should the privilege be considered violated by requiring the accused to talk to a psychiatrist to determine sanity at time of trial or at time of offense? Shall we say that there is a waiver of the privilege by urging the defense of insanity? Or should we say that he waives the defense of insanity (but not the privilege) unless he submits to examination? To determine insanity at time of crime, it is not cssential to ask the defendant about events of the crime. The courts have held that a defendant against his will can be 
an advocate, his opinion is expected to be biased and it is not used. ${ }^{38}$ The rule on insanity at the time of trial (which incidentally is a rule which arose in a day when defendants were not afforded counsel) is actually being used for purposes other than that for which it was intended. ${ }^{39}$ It is, on the one hand, used by defense counsel to

taken out of his cell and observed by a psychiatrist. See Hunt v. State, $248 \mathrm{Ala}$. 217, 27 So. 2d 186 (1946); Commonwealth v. Di Stasio, 294 Mass. 273, 1 N.E.2d 189 (1936); State v. Riggle, 298 P.2d 349 (Wyo. 1956).

The American Law Institute's Model Penal Code suggests a statute which reads in part as follows:

A statement made by a person subjected to psychiatric examination or treatment ... for the purpose of such examination or treatment shall not be admissible in evidence against him in any [criminal] proceeding on any issue other than that of his mental condition but it shall be admissible upon that issue, whether or not it would otherwise be deemed to be a privileged communication. A.L.I. Model Penal Code, Ten. Draft No. 4, $\$ 4.09$ (1955).

Under the present law the mental examination is ordinarily limited to a determination of present mental capacity to proceed. See, e.g., LA. REv. STAT. \$ 15:267 (1950). However, when the defense of insanity at the time of the crime is urged and "becomes an issue in the cause," an examination will be requested which includes a determination of the defendant's mental condition at the time of the crime. See State v. Chinn, 229 La. 984, 87 So. $2 d 315$ (1955), 17 LA. X. REv. 411 (1957). As a result of this procedure, the medical expert is led to believe that the defendant is not ready for trial unless and until he satisfies both the MCNaghten test and the test of triability. Cases are reported where psychiatrists have used the McNaghten rule for criminal responsibility in measuring competency to make a will. See GuTrMacher \& Weihofen, Psychitriy and the LAw (1952); Usdin, The Medical Expert, 257 NEw ENG. J. OF MED. 1220 (1957). One must remember that physicians are trained in medicine, not law. They are not judges or lawyers in disguise.

Certainly, the reliability of the psychiatric evaluation of the defendant's state of mind at the time of the offense would be enhanced by immediate or early examination, and for this reason, a comprehensive examination of the defendant's state of mind at the time of crime as well as at time of trial has merit. One might consider the position of the psychiatrist trying to determine the defendant's state of mind at the time of the offense many months or years after the offense. Cases are not infrequent where a psychiatrist is asked to report on a person's state of mind at the time of the offense some fifteen to thirty years after the offense. The defendant may have been in a psychotic state at the time of the offense and in a state of remission at the time of trial. The examination, from the viewpoint of reliabihty, ought to be near the time of the offense. The physician appointed to determine the defendant's triability is not always reappointed on the lunacy commission to determine sanity under the test of responsibility, or even if he is, he may not have focused at the initial interview on state of mind at time of act.

Provision for appointment of impartial expert or government hospital examination is made in Alabama, Arkansas, California, Colorado, Connecticut, Delaware, Florida, Hawaii, Indiana, Kentucky, Louisiana, Maine, Maryland, Massachusetts, Michigan, New Hampshire, New York, North Carolina, North Dakota, Ohio, Oregon, Pennsylvania, Rhode Island, South Carolina, Tennessee, Utah, Vermont, Virginia, W. Virginia, Wisconsin, Wyoming, District of Columbia and federal courts. See Goldstein \& Fine, The Indigent Accused, The Psychiatrist and the Insanity Defense, 110 U. PA. L. REV, 1061 (1962).

${ }^{38}$ See Szasz, Psychiatry's Threat to Civil Liberties, National Review, Mar. 12, 1963, p. 191 , at 192 .

${ }^{30}$ Weihofen years ago suggested that any reform in the method of trying persons 
delay a trial until the emotions of the prosecuting witnesses and the public have calmed, or better yet, until their memories have faded so that the district attorney cannot prove the case "beyond a reasonable doubt." The plea decreases the probability of prosecution. ${ }^{40}$

While present incapacity to stand trial is usually urged by the defense, it may also be raised in many jurisdictions by the district attorney or on the court's own motion. While ostensibly for the benefit of the accused, this procedure often works to deprive him of his constitutional right to a speedy trial. When defense counsel is available, there is little justification in allowing the plea of present insanity by the state. Quite frequently, the district attorney raises the issue of unfitness to proceed so as to put "undesirables" away in cold storage without the benefit of trial. (They may not be convicted either under the McNaghten or other rules or for lack of evidence, or they may not be committable under the mental health laws.) ${ }^{41}$ The criminal charge serves as little more than a fictional jurisdictional excuse for indeterminate confinement. ${ }^{42}$ Criminal colonies for the insane are filled to a considerable extent with mental

alleged to be insane probably will come through devices for preventing the trial of mentally disordered persons, rather than through a change in the substantive law or procedure relating to the question of responsibiltiy. WEIHOFEN, MENTAL Disorders as a Criminal Defense 428 (1954).

so Summoned to court but frustrated in giving testimony under the McNaghten rule, strictly applied, some psychiatrists turn to the present capacity rule to tell their tale. Usually as a part of defense strategy, it achieves the same end of avoiding the imposition of criminal punisbment. Consider the colloquy published in Symposium: The Law and Psychiatry, 109 J. OF LA. STATE MED. Soc'y 141, 157 (1957).

"1 On the right of the State to raise the issue of competency, see Foote, $A$ Comment on Pre-Trial Commitment of Criminal Defendants, 108 U. PA. L. REv. 832 (1960); Silving, The Criminal Law of Mental Incapacily, 53 J. CRuM. L. C. \& P. S. 129 (1962); see also State v. Swails, 233 La. 751, 66 So. 2d 796 (1953). Former Maj. Gen. Edwin A. Walker, following the rioting on the University of Mississippi campus, was ordered to undergo psychiatric examination. The United States Attorney maintained the order was legal, saying that such examinations are permissible any time after an arrest. AP News-Release, Nov. 21, 1962. The ACLU, among others defended General Walker's Sixth Amendment rights to a speedy and public trial which the government allegedly sougbt to deny by committing him to a "mental prison." See ACLU Weekly Bulletin No. 2154 (Oct. 15, 1962); Editorial, The Nation, Jan. 12, 1963. "If uncontested, the examination would have been carried out by government psychiatrists at the Federal Medical Center in Springfield, Missouri. Is this sound procedure, particularly since the U.S. Government is a party to the litigation against Walker? Yet, this is how the law stands, and how it is ordinarily administered. Imagine that instead of General Walker, the defendant is John Doe. How would he defend himself against the charge-for that's what it is-of mental illness?" Szasz, Psychiatry's Threat to Civil Liberties, National Review, Mar. 12, 1963, p. 179. Poet Ezra Pound spent World War II broadcasting for Mussolini. The U.S. found him mentally unfit to face treason 
defectives, usually harmless individuals. Take, for example, the person who makes a nuisance of himself by peeping into a woman's bedroom. He is picked up on a charge of vagrancy which carries a light penalty, but as he is usually a mental defective, he will never be able to understand a trial or assist counsel, and he spends the rest of his days forgotten in a criminal colony. His chance of ever being put to trial is rare, but should it occur, time in commitment is not credited toward sentence. ${ }^{22}$

What is the nature of the mental disorder or deficiency that requires a stay of criminal proceedings? ${ }^{43}$ Mental illness, standing

charges and he spent twelve years in a federal hospital. He has been living in Italy since 1958. See Szasz, Politics and Mental Health: Some Remarks Apropos of the Case of Mr. Ezra Pound, 115 Am. J. Psychiatry 508 (1958).

The confidentiality of communications is also a matter of concern. See A.L.I. Model Penal Code, supra note 37. See also Slovenko \& Usdin, Privileged Communication and Right of Privacy in Diagnosis and Therapy, 3 Currfort Psrchintric Therapies 277 (Masserman ed. 1963).

52 All too often, when a conviction cannot be obtained on the merits, the court and the district attorney ignore or overrule a finding by the confining institution that the individual should be returned to court. Consider:

A 35-year old 'forgotten man' committed to the East Louisiana state hospital at Jackson 15 years ago was released from custody Monday. Ordered released was Cleveland Journet, Negro, 35, who was committed to the mental institution in 1946 after a lunacy commission declared him incompetent to stand trial for simple burglary. ... The case against him was dismissed seven years ago by the district attorney's office as being 'too old' for further prosecution but word of this apparently never reached officials at the hospital. New Orleans TimesPicayune, Oct. 24, 1961, p. 3, §3, col. 3 .

See also de Grazia, The Distinction of Being Mad, 22 U. CHI. L. REv. 339, 349 (1955).

'B Mental illness, mental deficiency or physical disabilities are grounds to stay a trial. In some cases, the defendant may never be in a position to stand trial. For example, mental defectives, as noted, do not and cannot recover. On mens rea of the feebleminded to commit crime, see Pieski, Subnormal Mentality As a Defense in the Criminal Law, 15 VAND. L. REv. 769 (1962).

Trial is delayed in the case of a paranoid individual who is obviously wrapped up in a delusional system which encompasses events on trial.

Capacity to stand trial includes the ability to recall events so that the accused can furnish his counsel with facts needed to present his defense. State ex rel. Davey v. Owen, 133 Ohio St. 96, 12 N.E.2d 144 (1937). Some individuals however are likely to react to the emotional trauma of committing a crime by a process of forgetting. A passive individual who on a rare occasion bursts out in anger may blot out all recollection of the commission of a crime. Recollection via psychoanalysis or sodium amythal may result in psychotic breakdown. The separation of the malingerer from the genuine amnesic is difficult and requires a long period of observation, and can then usually be ascertained by the jail attendant. See Mayer-Gross, Saiter \& Roth, Clinical Psychiatry 133 (1955); Coburn \& Fahr, Amnesia and the Lazv, 41 Iowa L. REV. 369 (1956); Diamond, The Simulation of Sanity, 2 J. OF SoctaI. TherApy (1956); Slough \& Wilson, Mental Capacity to Stand Trial, 21 U. PrTT. L. REv. 593 (1960). Among frequent cases, one was recently reported that a negro woman suffering from amnesia was committed to the criminal colony in a "hospital" rathcr than brought to trial for murder because she was unable to remember the circumstances of the crime 
alone, is not tantamount to mental incapacity to stand trial. It seems that the law intends a postponement of trial only when the individual is obviously disoriented and his mode of communication is so radi-

and assist her defense. See Louisiana State Law Institute, Code of Criminal Procedure Revision, Exposé des Motifs, No. 19, p. 3 (Mar. 8, I963). A defendant may have no recollection of behavior while under the influence of alcohol. One court has held that a defendant who is an alcoholic and suffers from "alcoholic amnesia" is fit to stand trial, since it is not "a result of a mental disease or defect." See State v. Palmer, 232 La. 468, 94 So. 2d 439 (1957).

Physical illness may be claimed to stay a trial, perhaps indefinitcly. An individual may be so aged, or so deaf, that he is unable to hear any of the proceedings at the trial, but here a remedy is to read or repeat the testimony to him. Felts v. Murphy, 201 U.S. 123 (1906). A deaf-mute, or one who speaks in a low unclear voice, and is unable to write, is not able to go to trial. An individual may not be able to go to trial because of a heart condition. New Orleans Times-Picayune, Dec. 18, 1962, p. 13, $\$ 1$. col. 3.

Convicted Soviet spy Robert Soblen, suffering from incurable lymphatic leukemia, contended that necessary medication caused him to sleep throughout the trial proceedings and thus on appeal he argued that he should not have been put to trial. He spent most of the trial curled up in a special contour chair, specially rented by the court. Most of the time his eyes were closed. National Observer, Sept. 17, 1962. "When the case was reached for trial, Dr. Soblen's condition had deteriorated and he could not function in the courtroom without having heavy sedation and the administration of other drugs. Sedatives administered included demerol, thorazine, other tranquilizers and other analgesics. He was also on cortisone preparations both before and during the trial. By the very nature of that form of leukemia, Dr. Soblen would have been frequently in great pain throughout the trial due to pressure of the enlarged spleen and enlarged liver. This made it frequently difficult for him to sit. Toward the end of the trial his condition worsened to such a degree that it was necessary for him to lie on a couch in the courtroom which he did by leave of the court. He was in a sleepy state during a great part of the trial and was frequently, even when awake, unable to follow the trial proceeding. ... Under the circumstances, we fcel that defendant was deprived of his day in court. While he was physically present, albeit in a horizontal posture, his state of mind, induced by required sedation, made him mentally absent. This would be so even in an ordinary case; it is much more true in a case involving the dramatic tensions of brother testifying against brother, of testimony covering a span of 40 years, and of circumstances which demanded a mind most alert, perceptive and vigilant." Brief of Amici Curiae in support of petition for writ of certiorari in Soblen v. United States, May 29, 1962, pp. 2-3, 5.

In a trial in early 1962 in Dallas, William E. Lydy refused to talk to his courtappointed defense lawyer, who as a result did not know how to present a defense. The defendant went on a food strike, and in a limp condition he had to be taken in a wheelchair to court.

There are individuals who pull themselves together in the criminal unit at the hospital simply by being left alone, but they may relapse when returned for trial due to brutality at the local jailhouse or to the rigor of unduly vigorous cross-examination at trial.

The Georgetown University Law Center and the Judicial Conference of the District of Columbia Circuit in 1962 undertook a comprehensive study of the law in theory and practice relating to pre-trial mental examination in criminal cases in the District of Columbia. Statistical studies are being made relating to motions for mental examination and disposition thereof, as well as studies reflecting the attitudes of local judges, prosecutors, defense counsel and psychiatrists, and also the type and scope of the mental examination. 
cally, severely and clearly different from that of other persons that it is obvious to one and all. The law has gone off on a tangent, however, and looks about for some sort of expert. A psychiatrist is acknowledged in effect as a high priest to decide whether a person will go on trial. More often than not, the demands of private practice or crowded institutions preclude a competent psychiatric examination (even assuming that it were needed), or the task is performed as a dull chore. ${ }^{44}$ The expert all too frequently expresses an opinion on nothing more than a ten to sixty-minute interview, ${ }^{45}$ and for his efforts he is paid an unusually handsome fee. ${ }^{46}$ Actually, the jail attendant, experienced with the criminal element and able to observe the accused around the clock, can make an evaluation sufficiently adequate to assist the court in determining capacity to stand trial. The attendant's crude description, "he's a psycho" or "weirdo," is all that is needed. Anything more subtle than what the jail attendant can detect ought not to be a basis to stay a trial, and indeed results in injustice and perversion of the criminal process. Besides, a psychiatrist's evaluation which does not follow the at-

* There are, of course, examiners who patiently and diligently undertake the task of examination, and accept the responsibility only when they can do so.

is A medical diagnosis sometimes can be made in a few minutes, e.g., of a nonmalingerer who sees butterflies flying around his head, but not so of a person who is not completely fallen apart. The following statements, on file, by persons "examined" by members of lunacy commissions indicate the nature of the examination, which is occurring frequently: "He asked me a few little things, the whole of five minutes I would say. He asked me a few little things about my private life and then he left." "He talked to me for a whole three minutes. He didn't even look at me and then on the stand he is swearing ... but, actually, when I say three minutes I might be saying that to emphasize the fact that it was no examination and I wasn't talked to at all." "I will give him maybe five mintues that he talked to me." "He didn't even stay three minutes." "He came in, said 'hello' and asked me my father's name and then he said "that's all.'" The brevity of the examination, while it may be criticized for other reasons, may well indicate that capacity to stand trial is determinable by the obvious (while, for diagnosis for psychotherapy, a different type of examination, one in depth, is necessary).

40 The usual fee is $\$ 150$ in Louisiana, $\$ 100-250$ in Ohio, $\$ 100$ in Connecticut. See Goldstein \& Fine, The Indigent Accused, The Psychiatrist, and the Insanity Defense, 110 U. PA. L. Rev. 1061 (1962). Justice Brennan of the Supreme Court expresses the opinion that psychiatrists should give their services free to indigent defendants who plead insanity. Brennan, Law and Psychiatry Must Join in Defending Mentally Ill Criminals, 49 A.B.A.J. 239 (1963).

More often than not, psychological testing, consisting of a battery of tests (while an abstraction of an abstraction), can be more helpful than the report of the psychiatrist, which is usually based on a brief interview. The United States Court of Appeals for the District of Columbia, in Jenkins v. United States, 307 F.2d 637 (D.C. Cir. 1962) ruled that qualified psychologists may present to juries expert opinions about the mental condition of a defendant when insanity is an issue. 
tendant's appraisal is suspect and subject to further investigation. ${ }^{47}$

It is not proposed that the jail attendant should supplant the psychiatrist as the "expert" on an accused's fitness to stand trial. The point is that fitness to stand trial ought to be measured by an ordinary view. The judge really ought to judge, in theory as well as in fact. He can by himself make the decision on the basis of a few ordinary and simple questions put to the defendant (e.g., What is the year? Who is the President of the United States? What are the colors of the American fiag?). There is no need for a diagnosis in depth. One must make an examination for the purpose that it is going to be used. The sort of evaluation needed for measuring triability is not the same as that needed for medical treatment or other purposes.

The question of fitness to plead and stand trial is really much more urgently in need of attention than is the McNaghten rule.

\section{IV}

\section{Capacity to Stand Execution}

There is another stage in criminal proceedings involving mental capacity. An individual who is considered legally sane at the time of offense and throughout the trial proceeding may become insane at the time scheduled for execution. There is a rule of law, founded on dubious reasons, that a psychotic person cannot be executed (but a sane person can be). ${ }^{48}$ In the United States, it usually takes several

\footnotetext{
tHess \& Thomas, Incompetency to Stand Trial: Procedures, Results, and Prob. lems, 119 Am. J. OF Psychiatry 713, 719-20 (1963). Lay witilesses under the law of evidence are allowed to give an opinion on mental condition. Connecticut Mut. Life Ins. Co. v. Lathrop, 111 U.S. 612 (1884); 25 TUL. L. REv. 518 (1951), 7 Mo. L. REv. 60 (1942).

48 The rule that an insane person cannot be executed is well established, but the logic and policy behind the rulc is vague. The explanations for the exemption rule include: (I) if the defendant is sane he might urge some reason not previously considered why the sentence should not be carried out (yet the same logic would suffice to postpone, perhaps indefinitely, the execution of a sane man, for time for intelligent reflection may disclose new reasons for stay of execution of the sane as well); (2) killing an insane person does not have the same moral quality as killing a sane person; (3) a person should not be put to death while insane because in that condition he is unable to make his peace with God. Under the law, the imposition of the petralty is required when the prisoner is restored to sanity. See Hazard \& Louiscll, Death, The State, and the Insane: Stay of Execution, 9 U.C.L.A. L. REv. 381 (1962).

In the majority of states, the issue of post-conviction insanity may be raised only by the warden (or sheriff) having custody of the prisoner. The United States Supreme Court, in Solesbee v. Balkcom, 339 U.S. 9 (1950), said that the manner of procedural
} 
years before legal maneuvers have been exhausted, 48 and by that time, the prisoner, sitting in isolation on death's row, has a mental breakdown, or he feigns it to save his neck. He is thereupon transferred to the security area of a hospital where he usually lives out the rest of his days. ${ }^{50}$ Here again the law casts upon the physician a non-medical question: Tell us when this man is ready to be electrocuted. The test supposedly is that the condemned person must

effectuation of exemption for insanity is a matter of grace, not of right, and hence the state is under no obligation to provide a hearing. Thus, the execution of the capital penalty lies very much in the attitude of the warden toward the penalty.

'Lunden, Time Lapse Between Sentence and Execution: The United States and Canada Compared, 48 A.B.A.J. 1043 (1962).

${ }^{60}$ Malingering is often difficuit to ascertain. Even though a person is acting, he may still be psychotic. A person close to psychosis can readily act it; he can feel it. A person would have to be observed over a period of time in order adequately to establish a diagnosis. Prisoners on death row as a last resort usually feign insanity in order to escape a pending execution. They learn, either from their attorneys or from the grapevine, that under the law psychosis precludes execution, and they act upon the information. However, in most cases, attorneys do not suggest or direct the patient to act in a psychotic manner, but simply advise on the law. The following is typical, and is from a tape recording:

Examiner at hospital: "Tell me what happened at the penitentiary to make them send you to the hospital."

Patient (formerly prisoner): "Nothing."

Examiner: "Huh?"

Patient: "My lawyer came and got me."

Examiner: "Your lawyer came and got you? Are you afraid of dying?"

Patient: (No answer).

Examiner: "Did your lawyer tell you what to do to get out of there?"

Patient: "No."

Examiner: "Looks to me like a good lawyer would have told you how to act. He didn't tell you how to act?"

Patient: (Inaudible mumbles).

Examiner: "I didn't understand you. He told you to act crazy?"

Patient: "Un-hum."

Examiner: "What did he say?"

Patient: "He kept telling me to . . . (inaudible)."

Examiner: "Kept telling you what?"

Patient: "The last time he came up . . . (inaudible)."

Examiner: "The last time he came up, what did he do?"

Patient: "He asked if I ever had an epileptic fit."

Examiner: "What did you tell him?"

Patient: "I told him no."

Examiner: "What did he say then?"

Patient: "He said that an epileptic fit was the last straw." [In the lingo, an epiJeptic fit is the way of a crazy man.]

Examiner: "He told you this?"

Patient: "Yes."

Examiner: "Did he tell you how to act?"

Patient: "No, he didn't want to incriminate himself."

Examiner: "He told you that he did not want to incriminate himself?"

Patient: "That's right." 
realize he is to be electrocuted for the crime he has committed. Yet this test can be applied by the jail warden, if we are to have such a test. As applied, the physician is asked to get his patient well so that he can be electrocuted-a curious footnote to the Hippocratic oath. ${ }^{\text {s1 }}$

The procedure casts upon the physician the responsibilty of the execution of the death penalty. The judge at the trial is relieved of the decision by the jury, a group so large that individual responsibility is lost. Yet, in the end, the law places the decision on one individual-the physician. It is not surprising that physicians are reluctant to oblige. Literature is abundant urging the abolition of the death penalty. To a considerable extent, the discussion on the death penalty is much ado about nothing. Criminals are sentenced to death, but in recent years the execution of the sentence is the exception rather than the rule. ${ }^{52}$

In addition to the rule that a condemned man cannot be executed while insane, the law also makes mention of prisoners under sentences for life or years, but the provision has little practical application. It is indeed a rare prisoner who seeks a transfer from prison to the security unit of a mental institution, where conditions are deplorable and where he is likely to be forgotten for the rest of his life. The claim of insanity as an exemption from punishment is exercised almost always only by death row prisoners who have exhausted all legal maneuvers to stay execution.

The exemption from execution, just as the right-wrong test of criminal responsibility and the test of capacity to stand trial, presents a non-medical question, yet here again a physician is delegated the

\footnotetext{
Examiner: "So he didn't tell you how to act. But he got his point across to you?" Patient: (Inaudible). fits?"

Examiner: "Huh? How did you know how to act when he told you about epileptic

Patient: "I just knew."

${ }^{51}$ As one might well guess, proguosis is quite poor as there is no motivation for recovery. The physician is also placed in an awkward situation as should treatment result in recovery, it can only be detrimental to the inmate.

${ }^{82}$ The actual execution of the death penalty is localized in a few states, namely, California, 8 in 1961; South Carolina and Mississippi, 5 each; Virginia, 4; and Gcorgia and Texas, 3. At the beginning of 1961 , there were 212 prisoners in the United States under the sentence of death. During 1961, a total of 136 prisoners received death sentences, bringing the total cases under a death sentence to 348. During 1961, 42 were executed. The aforementioned 6 states, out of 44 jurisdictions whose statutes provide for legal execution, accounted for 28 or two-thirds of the 42 executions carried out in 1961. National Prisoner Statistics, No. 28 (April 1962).
} 
decision. The rules on capacity to stand trial and to face execution are being used today paralegally, one might say $s u b$ rosa, to achieve ends which may or may not have merit. The rule on capacity to stand trial is being subverted to avoid a trial or to put a person in cold storage. The rule on insanity at time of execution is being used to avoid the law on capital punishment.

It has been stated that laws ought to be formulated and applied with a view towards existing institutions, otherwise they are impractical or imprudent. Yet, the raison d'etre of security treatment units in a public hospital, where individuals are sent who are unable to stand trial or who become psychotic in prison, has yet to be studied. The need for such units is still to be demonstrated. All that is accomplished, if anything, in a criminal unit in most hospitals can be better accomplished in prison. Strange as it may seem, prisons usually have more to offer now in the way of facilities for the inmate, as well as in the way of protection against escape. ${ }^{53}$ Inmates in hospital security units usually sit day in and day out in a congested and smelly room, and idly look at television. There is no one to supervise work activities or anything else. Hospital attendants with a modicum of intelligence and medical supervision administer drugs, and this can equally well be done at the prison. Individuals awaiting trial or execution can do their waiting in prison.

\section{V}

\section{Mental Abnormality in Relation to Crime}

The point of all this is that the law should make use of the knowledge of other disciplines, not cast upon them the responsibility of making its decisions. In the area of criminal administration, the law ought not to ask the physician whether the accused knew right from wrong, or whether the accused understands the nature of trial and how to assist counsel, or the meaning of execution. Yet, the

\footnotetext{
${ }^{58}$ Many hospitals directors have expressed concern about sending certain defendants to "security treatment units" in hospitals. The unit usually has inadequate facilities and attendants for guarding them. The unit, to say the least, has minimum security protection. Curiously enough, death row patients transferred from the penitentiary to the hospital are warned that misbehavior will result in their being sent back "to fry." The capital-penalty abolitionist ought to take note that here, where imposition of the death penalty can be expected, it serves as a deterrent. Every now and then, the hospital director, to show he means business, returns an unruly inmate to the penitentiary. These account for the majority of executions actually carried out.
} 
law does these things and then some spokesmen complain that the law is being supplanted by other disciplines.

Profesor Hall, among others, contends that psychiatry makes nonsense of personal responsibility. The criticism is very much in vogue these days that psychiatry is undermining individual responsibility. Freudianism is allegedly the culprit for contemporary American permissiveness. It is curious to see that the attack on Freud and his discipline comes from opposite directions. The Marxists dismiss Freud as "subjective" or idealistic. Professor Hall, and others, criticize the discipline as being "deterministic."

Psychoanalysis sets a high value and standard on a human being. A person is seen an enormous amount of time in a dyadic relationship. He is seen by one person (admittedly at a substantial monetary reward) for hundreds of hours in psychoanalysis (and to a lesser but still considerable extent in other fields of psychiatry). There is no other endeavor where a person receives such undivided attention. It is a premium placed on the individual unheard of in totalitarian systems.

It must be noted that patients in psychotherapy are taught to pay attention to, and assume responsibility for, their behavior. Successful therapy calls for hard work on the part of the patient, often more painful than a major operation. A person cannot be treated until he feels he is responsible. Indeed, respect for the basic dignity of human beings assumes that they are responsible individuals who, even in their sickest state, know right from wrong and retain some elements of choice, however small. All delinquents are responsible for what they do, and no matter how mentally ill or bizarre they seem to be, they are best treated as responsible individuals. At some clinics even a psychotic who, for example, breaks a lamp is made to pay for it. ${ }^{5 t}$

Consideration of the individual as responsible is a force which plays a role in the behavior of a person. The term "determinism,"

54 The neurotic does not get well until he accepts responsibility, and for example, no longer blames mother for what she did to him when he was young, although what she did continues to hurt. In the case of the overtly psychotic, the therapist is the ego for the patient and accepts responsibility for him, until bit by bit the patient, incorporating the ego of the therapist, is able to pull himself together. On treating the delinquent as responsible, see Szasz, Psychiatry, Ethics, and the Criminal Law, 58 Colvm. L. REv. 183 (1958). For the views of another writer who values highly the place of responsibility, see Haines, Dispensing With Responsibility, 38 PHrosophy 69 (1963). 
properly used, means simply that inner and outer forces have an effect on a person. Some forces have more effect than others, but all have an effect. The abnormal person does not react rationally to the influences of the outer world but reads past situations into them. He does not react to outer stimuli appropriately, but always according to definite patterns or reaction acquired in the course of childhood. The past always predominates because, not differentiating sufficiently between present and past, he always misunderstands the present in the sense of his unsolved past. As the saying goes, the abnormal person is forever being blackmailed by his childhood. Psychotherapy hopefully will allow an individual to act without being so bound by the past. Psychotherapy aims at the rescue of the patient from a psychopathological state. Neurosis means maladaptive behavior; the past inappropriately governs the present. We all wish at times that we could act differently, but some memories adversely influence us. A kleptomaniac or pyromaniac, for example, is driven to steal or burn almost as forcefully as one must have a bowel movement. He does not act "freely." An individual's action at any given moment are the product of all the forces, external and internal, past and present, which have played on him and are playing on him. New forces and influences, however, are continually being added which may alter the end product. Therapeutic influence is a new causal factor brought to bear on the patient. Psychotherapy as a new determining influence in the patient's life can be optimistic only because of the principle of determinism. ${ }^{55}$

Although it is easier to be retrospective than prospective, the news media and lawyers bring the house down on psychiatry whenever the perpetrator of a crime had previously been in treatment or hospitalization for a mental disorder. The psychiatric profession,

st Robert P. Knight observes that the divergence in views between law and psychitry is not over the question of responsibility-both law and psychiatry assume individual, personal responsibility, and that there is actually no issue here of "free will." Knight states the divergence is over the question of what should be done with those whose unlawful acts indicate that their sense of personal and social responsibility is insufficient to hold their behavior within the law. The lawyers declare that when laws are broken the culprits must be convicted and punished. The psychiatrists say that punishment has no salutary effect on many such persons; that some of them are uninfuenceable by any known methods of management and therefore must be restrained for the protection of society; but that many would be more likely to become rehabilitated through treatment and re-education, were it available, than through punishment. See Knight, Determinism, "Freedom" and Psychotherapy, 9 PsychIATRX 251 (I946). 
they say, is responsible for "accurate prognosis." The community is "perturbed by the massive evidence that persons guilty of spectacular violence are so often alumni of one of the many psychiatric institutions. ... No doubt the doctor will sometimes fail, despite his best effort; but an uneasy laity will be hard to convince that he must fail his obligations as frequently as he has been failing them in recent years." It is interesting to compare, on the other hand, the lack of concern over present-day prison policy, which is ludicrous in the extreme. It is estimated that between 70 to $80 \%$ of persons released from prison commit further crime and are back again in a couple of years. Present-day prison policy is to let a prisoner out the back door as one is brought in the front door. A life sentence is served on a revolving installment basis, with crimes in between. Every dog is entitled to one bite; a criminal in a democracy, some seem to say, is entitled to two murders, but, believe it or not, there are in prison (and outside) three and four-time murderers. In many communities there is a flagrant failure to enforce the criminal laws. Wiliam H. Parker, Chief of Police of Los Angeles, observes:

I don't say that there aren't crimes committed by persons who will not repeat the act. I think there definitely is a field for rehabilitation. But many criminals are hardened by the time they get into the penitentiarythey have been dealt with again and again, first as a juvenile and in no custody, then in the lower courts and in community jails. By the time they arrive in the penitentiary they are confirmed criminals. ${ }^{67}$

Yet here the lawyer and the public are strangely silent and turn their face the other way like the three little monkeys of no evil.

Psychiatrists are expected to make predictions about mental patients in terms of absolute certainties, an impossibility, even though the evidence has none of the glaring nature and is not as solid as that concerning the habitual criminal. The contrast in attitudes is indeed remarkable. One reason for the cold storage of individuals who are committed to a hospital criminal colony is the court order asking the psychiatrist to predict that there is absolutely no danger in discharge. It seems that here the court, not psychiatry, is proclaiming a doctrine of complete, universal determinism. No

\footnotetext{
6o Johnson, Psychiatrists and the Public, New Republic, Dec. 8, 1962, p. 12 . Sec New Orleans States-Item, June 1, 1962, p. 1; Nov. 14, 1962, p. 1; Pittsburgh Press, June 1,1962 , p. I.

${ }^{87}$ Interview by Donald McDonald with William H. Parker, The Police, Center for the Study of Democratic Institutions (1962).
} 
one-not even a psychiatrist-can honestly make a prediction as accurate as here demanded by the court. The psychiatrist generally refuses to make such a prediction, and the individual sits in confinement. This state of affairs is not due to the "youth" of psychiatry. It is inherent in the nature of things. A condition of predicting is information about all relevant parameters. As Waelder puts it:

Nobody can expect predictions when relevant parameters are unknown. The physicist predicts what will happen in an artificial set-up of his own construction-e.g., in an electronic tube--the parameters of which are known to him. But he will not predict what will happen inside a volcano where conditions are only incompletely known-whether or not it will erupt within a certain period of time.

Similarly, it makes no sense to expect a psychoanalyst to predict a particular person's future behavior which depends, in part, on future events in this person's environment and the kind of stress or opportunity that he will meet, as well as on future developments in his bodily organism (as illnesses); these are all factors which may be determined in their own way, but which the analyst has no way of knowing. As the physicist predicts not what happens in empirical systems but rather what happens under specific conditions, so the analyst can reasonably be asked to predicts not what happens in empirical systems but rather what happens under unknown conditions but as it will be under specific conditions. Thus, we cannot expect him to say what the future destiny of his analysand will be, but he may be asked to predict how this analysand would stand up to a particular stress, for example, to a traumatic experience of the kind that had started him on his neurosis ....

He will also judge, in some cases, that the patient will be able to deal with ordinary pressures without renewed breakdown; in others, that he will be able to deal with such mild pressures only as he may meet in a favorable environment; and in a few cases, perhaps, he will be confident that the patient can meet whatever comes....

In any case, [predictions of this kind] . . . are merely probabilistic; they predict a probable, not a certain development. ${ }^{58}$

As regards the test of criminal responsibility, strict constructionists, in the way they view and apply things, are caught between the Scylla of McNaghten, where few are exempt from criminal responsibility and punishment, and the Charybdis of Durham and

${ }^{83}$ Waelder, Psychic Determinism and the Possibility of Predictions, 32 Psychoanalytic Q. 15, 30-31 (1963). See also Booth, Values in Nature and Psychotherapy, 8 ARChives OF Gen. Psychiatry 22 (1963). Science of the present time does not claim absoluteness or infallibility, or "iron laws of necessity." It yields probable knowledge, on which we act. See Lee, $A$ Criticism of the Marxian Interpretation of History, 1 Tulane Studies in Philosophy 95 (1952); Slovenko, Establishing the Guilt of the Accused, 31 Tut. L. Rev. 173 (1956). 
Currens, where everyone is exempt from criminal responsibility. Professor Hall and others, unfortunately equating symptom formation with mental illness, quote psychiatrists as saying that "all Americans are mentally diseased," and hence, in the event of commission of crime, acquittal would result under the new-fangled Durham or Currens tests of criminal responsibility. The recent Mid-Manhattan Study on Mental Health is quoted as holding that $82 \%$ of the residents are mentally ill.59 But it should be noticed that this study actually does not attempt to make a nosologic diagnosis (psychotic disorder, psychoneurotic disorder or personality disorder). ${ }^{60}$ The ratings in this study were: well-18.5\%; mild symptom formation$36.3 \%$; moderate symptom formation-21.8\%; marked symptom formation-13.2\%; severe symptom formation-7.5\%; incapacitated $-2.7 \%$. This survey measures not mental illness but degree of mental health. The fact that a majority of the population shows symptom formation (e.g., a headache) does not mean that they are mentally ill, but that they have not achieved the degree of mental health that would have desirability. The question of mental illness arises in the case of persons who show severe symptom formation or who are incapacitated.

What is the standard of "normality"? Diagnosis is not made solely, as it is sometimes implied, by the degree of deviation from social norms. ${ }^{61}$ Mental health is not an indiscriminate adjustment through positive acceptance of environmental conditions. Bettelheim has described the severe psychic distortions that resulted from a passive adjustment to and acceptance of the environment in the concentration camps. A healthy individual does more than merely adjust to his environment; he makes the environment adapt to him as well. Freud, when asked what he thought a normal person should do well, is reported to have said: "Lieben und arbeiten" (to love and to work). ${ }^{62}$

Psychoanalysts might say that if one goes "deep enough" in ex. amining the psyche of an individual, unconscious material laden with

\footnotetext{
${ }^{59} \mathrm{Hall}$, op. cit. supra note 4.

oo See Srole, Langner, Michael, Opler \& Rennie, Mental Health in the Metropou is (1962).

'1 Hall, op. cit. supra note 4.

${ }^{2}$ Epstein, Concepts of Normality or Evaluation of Emotional Health, 3 BeHAvioral SCIENCE 335 (1958). See also Redlich, The Concept of Health in Psychialry, Explor.. tions in SOcial Psychiatry 138 (1957).
} 
pathological conflicts will be found. While this may be true, the crucial factor is the individual's coping mechanisms. In a healthy individual the positive side is able to cope with the negative side. A healthy individual is not without conflicts. Rather, he is a person who is dealing with and has dealt with the conflicts of each stage of development in life in an esssentially satisfactory manner. ${ }^{63}$

One might say, in popular language, that all criminals have "something wrong with them." The "normal" criminal is indeed rare-the normal, or situational, criminal refers to persons who commit criminal acts only as a last resort in a situation which realistically, to them, offers no other solution. This would refer to the man who steals to prevent his children from becoming malnourished when he has been honestly unable to find a job, and no charity is available. Most offenders, however, are driven by emotional conflict and unconsciousness motivation, not by temporary overwhelming need. An individual who kills or rapes is deranged or is without feelings. This is not to imply, however, that ipso facto he should be acquitted or sent to a hospital.

Society must protect itself from the dangerous individual, whether his acts are free-willed or determined. Free will or sickness, or whatever one chooses to call it, is not an excuse to roam the streets and abuse others. Protection, however, does not come via McNaghten or by the other rules of criminal responsibility.

Regardless of its cause or meaning, criminal behavior by definition is harmful to society, and the offender must be isolated from society as long as he is likely to behave in the same destructive manner. Whatever treatment is performed must be carried out in a correctional institution until there is reason to believe that he will relate to the demands of society in a more constructive manner.

Criminological research over the past several decades has brought one point home time and time again. Rehabilitation of the criminal

\footnotetext{
${ }^{63}$ See ERIkson, Childhood and Soctety (1950).

Emotional health involves the following: absence of psychiatric structured symptoms, social and occupational adaptation and dynamic integration with the presence of only mild anxiety. In greater detail this does not imply that the individual does not have conflicts and problems, but that he is able to deal with such problems and conflicts in a manner which is satisfactory for himself and those around him, including the larger society. Emotionally healthy individuals are those who are able to achieve an optimal utilization of their innate endowment. Letter from Dr. N. B. Epstein, Chief Psychiatrist, Jewish General Hospital, Montreal, Canada, to author, Oct. 10, 1962.
} 
is usually impractical idealism, due both to his personality structure and the inadequacy of present-day treatment facilities and method. Freud maintained that early adolescence offers the last chance for modification of personality, and that thereafter its alteration in any radical way is a task of the utmost difficulty. ${ }^{64}$ It is what goes on between the child and his parents during the first two, perhaps five years, that has the profoundest shaping-not the only, but the profoundest shaping-of the individual for good or ill, the pattern of which underlies all later development. ${ }^{65}$ Freud's discoveries have given birth to the child guidance and playgrounds movement, since it has come to be appreciated that prevention is better than cure. It may now sound trite, but it is true: delinquency is best controlled by providing children with a home environment free of emotional stress and personal insecurity. By so educating the public, psychiatry is aiding the criminal law process by trying to keep people out of it. This is not subversion.

\footnotetext{
"Ecologists have pointed out a "critical" time in animal development. At that time inherent growth pattern of the animal can be changed by exposing it to experiences not consistent with environment in which growth occurs. Thus, a duck separated from the brood and attended by a human caretaker will not return to the duck society after that critical period. Similarly, there are critical periods in human development. See Mahler \& Furer, Cerlain Aspects of the Separalion-Individuation Phase, 32 Psychoanalymc Q. 1, 14 (1963). See also Erikson, Childhood and Society (1950); Josselyn, Illegitimacy, SEXual BeHavior AND THE LAw (Slovenko ed., in publication); Blaine, The Children of Divorce, The Atlantic, March 1963, p. 98; Carstairs, The First Years, 68 THE LISTENER 853 (1962); Halleck, The Criminal's Problem with Psychiatry, 23 Psxchiatry 409 (1960); Rogers \& Skinner, Some Issues Concerning the Control of Human Behavior: A Symposium, 124 Scrence 1057 (1956); Scott, Crilical Periods in Behavioral Development, 138 SCIEnCE 949 (1962).

os "All psychoanalytic theories agree generally that the beginnings of neurotic development must be sought in the vicissitudes of childhood growth. They differ in their emphasis on the particular factors in the child which are involved." Rubins, On the Early Development of the Self: Its Role in Neurosis, 22 AM. J. OF PsYchoANALYSIS 122 (1962).
} 